\title{
Cell-free supernatants of lactobacilli inhibit methicilin-resistant Staphylococcus aureus, vancomycin-resistant Enterococcus and carbapenem-resistant Klebsiella strains
}

Laktobasillerden elde edilen hücresiz süzüntülerin metisiline dirençli

Staphylococcus aureus, vankomisine dirençli Enterococcus ve karbapeneme dirençli Klebsiella suşlarını inhibisyonu

\author{
Fatma Kalaycı Yüksek ${ }^{1}$ Defne Gümüş ${ }^{1}$ \\ Yaşar Nakipoğlu ${ }^{3}$ \\ Rıza Adaleti ${ }^{4}$ \\ Derya Bayırlı Turan² ${ }^{2}$ \\ ${ }^{1}$ Istanbul Yeni Yüzyıl University, Faculty of Medicine, Department of Medical Microbiology, Istanbul, Turkey \\ ${ }^{2}$ Istanbul Yeni Yüzyıl University, Department of Clinical Microbiology and Infectious Diseases, \\ Istanbul, Turkey \\ ${ }^{3}$ Istanbul University, Istanbul Faculty of Medicine, Department of Medical Microbiology, Istanbul, Turkey \\ ${ }^{4}$ Sağlık Bilimleri University, Faculty of Medicine, Department of Medical Microbiology, Istanbul, Turkey
}

\begin{abstract}
Aim: Antibiotic resistance is a major health problem. Recently, probiotics are used in the field of alternative/supportive medicine. Thus, in this study, we aimed to evaluate the in vitro inhibitory effects of four different cell-free supernatants (CFSs) of lactobacilli species (L. fermentum, L. plantarum, $L$. acidophilus and L. rhamnosus) on clinically isolated Methicilin-resistant Staphylococcus aureus (MRSA) strains, Vancomycin-resistant Enterococcus (VRE) strains, and Carbapenem-resistant Klebsiella (CRK) strains.
\end{abstract}

Materials and Methods: Lactobacillus strains were grown in de Man Rogosa Sharpe broth; after filtration, CFSs were diluted to obtain 25,50 , and $100 \%$ concentrations. Pathogen bacteria were grown in tryptic soy broth with and without CFSs in a micro-plate. The bacterial growths were measured using spectrophotometric method after four hours of incubation at $37^{\circ} \mathrm{C}$. One-way ANOVA followed by Dunnett's multiple comparisons and Kruskal-Wallis test were used for statistical analyses.

Results: All tested CFSs at all concentrations were found to inhibit growth of MRSA, VRE, CRK strains; the results were found statistically significant $(p<0.0001)$. At $50 \%$ concentrations, all CFSs were found to be most effective on MRSA growth. The CFSs of L.fermentum, L.acidophilus and L.plantarum were found to be most inhibitory at $50 \%$ concentration on VRE growth. $50 \%$ diluted CFSs of L.fermentum and L.plantarum were found to be effective on growth of CRK. All results were found statistically significant $(p<0.0001)$.

Conclusion: In our study, our results support that CFSs of lactobacilli strains inhibit growth of multidrug resistant bacteria. Their inhibitory effects were dependent on microorganisms and CFS concentrations.

Keywords: Lactobacilli, Cell free supernatant, MRSA, VRE, CRK, growth inhibition. 


\section{öz}

Amaç: Antibiyotik direnci büyük bir sağlık sorunudur. Son yıllarda, probiyotikler alternatif/destekleyici tıp alanında sık kullanılmaktadır. Bu nedenle, çalışmamızda, dört farklı lactobacillus türünün ( $L$. fermentum, $L$. plantarum, L. acidophilus ve L. rhamnosus) hücresiz süzüntülerinin (cell-free supernatant, CFS) etken olarak izole edilen metisiline dirençli Staphylococcus aureus (MRSA), vankomisine dirençli Enterococcus (VRE) ve karbapeneme dirençli Klebsiella (KRK) suşlarının üremeleri üzerine inhibitör etkilerini in vitro saptamayı amaçladık.

Gereç ve Yöntem: Lactobacillus suşları de Man Rogosa Sharpe sıvı besiyerinde üretilmiştir; hücresiz süzüntüler \%25, 50 ve 100'lük konsantrasyonları elde etmek için sulandırılmıştır. Patojen bakteriler mikroplaklarda, farklı konsantrasyonlarda CFS içeren ve içermeyen triptik soy buyyonda üretilmişlerdir. Üremeler, $37^{\circ} \mathrm{C}$ 'deki dört saatlik inkübasyon sonunda spektrofotometrik yöntemle ölçülmüştür. Istatistiksel analizler, one-way ANOVA kullanılarak, Dunnett'in çoklu karşılaştırma testi ve KruskalWallis test ile gerçekleştirilmiştir.

Bulgular: Incelenen tüm CFS konsantrasyonlarının MRSA, VRE ve KRK suşlarının üremelerini inhibe ettiği saptanmış; sonuçlar istatistiksel olarak anlamlı bulunmuştur $(p<0.0001)$. Tüm CFS'lerin \%50'lik konsantrasyonlarının MRSA suşlarının üremesine en etkili konsantrasyon olduğu belirlenmiştir. L.acidophilus, L.fermentum ve L.plantarum CFS'lerinin \%50'lik konsantrasyonlarının VRE suşlarının üremesine en etkili konsantrasyon olduğu bulunmuştur. L.fermentum ve L.plantarum CFS'lerinin $\% 50$ 'lik konsantrasyonlarının, KRK üremesini en etkili biçimde inhibe eden konsantrasyon olduğu saptanmıştır. Tüm sonuçlar istatistiksel olarak anlamlı bulunmuştur $(p<0.0001)$.

Sonuç: Çalışmamızda sonuçlarımız denenen tüm laktobasil CFS'lerinin çoğul antibiyotik dirençli bakterilerin üremesini inhibe ettiğini desteklemektedir. Bu inhibitör etkileri, mikroorganizmalara ve CFS'lerinin konsantrasyonlarına bağlı olarak değişkendir.

Anahtar Sözcükler: Lactobacillus, hücresiz süzüntü, MRSA, VRE, KRK, üreme inhibisyonu.

\section{INTRODUCTION}

Multi-drug resistance is a very big problem all over the world leading to treatment failures of nosocomial and community-acquired infections and responsible for high morbidity-, mortality rates, increasing of health charges. Resistance to various beta-lactam antibiotics generated by different mechanisms is prevalent in Gramnegative and Gram-positive bacteria (1, 2). In the last few years, it has been reported that the rates of colistin resistance in Gram-negative bacteria are increasing $(3,4)$. Besides, multi-drug resistant bacteria isolated from nosocomial infections such as vancomycin-resistant Enterococcus (VRE) strains and methicilin resistant Staphylococcus aureus (MRSA) strains become a concerning problem after horizontally transferring of vancomycin resistance from VRE to MRSA strains $(5,6)$.

In the last few decades, some alternative treatment and/or preventive strategies were investigated $(1,7,8)$. Some previous studies suggested that probiotics can be used both for the protection from infections and as supplementary drugs for the treatment of infections especially caused by multi-drug resistant pathogens (9-15). Probiotics are characterized as living microorganisms that provide to promote host health (16). Lactobacillus species are known as the major probiotic microorganisms that have protective roles against pathogens by competing, secretion some antimicrobial substances against them, and supporting the host immune system (17-20).

In our study, it was aimed to investigate the effects of cell-free supernatants (CFSs) obtained from different lactobacilli (Lactobacillus fermentum ATCC 9338, Lactobacillus plantarum ATCC 14917, Lactobacillus acidophilus ATCC 314 and Lactobacillus rhamnosus ATCC 53103) on the growth of clinically isolated Methicilinresistant Staphylococcus aureus (MRSA), Vancomycin-resistant Enteroccoccus (VRE) and Carbapenem-resistant Klebsiella strains (CRK).

\section{MATERIALS and METHODS}

\section{Bacteria}

In the present study, 30 MRSA strains, 30 CRK strains, 30 VRE strains were isolated from patients administered to Sağlık Bilimleri University, Faculty of Medicine, Haydarpaşa Numune Hospital, Istanbul Yeni Yüzyıl University Faculty of Medicine, Gaziosmanpaşa Hospital and Istanbul University, Istanbul Faculty of Medicine, respectively. MRSA and CRK strains were isolated from various clinical samples 
(Table-1) and VRE strains were isolated from rectal swab samples.

The antimicrobial susceptibilities were determined by the disk diffusion method and automatized systems (VITEK-2) according to the European Committee on Antimicrobial Susceptibility Testing (EUCAST) guidelines.

L. rhamnosus ATCC 53103, L. fermentum ATCC 9338, L. acidophilus ATCC 314 and L. plantarum ATCC 14917 were investigated in the present study. These particular strains were chosen according to their widely usage in various products such as gums, fruit drinks, and medical tablets which are mainly available in both markets and pharmacies $(21,22)$.

Before the experiments, we stored all strains at $-80^{\circ} \mathrm{C}$.

Table-1. MRSA and CRK strains isolated from various clinical samples

\begin{tabular}{ccc}
\hline Sample & MRSA & CRK \\
\hline Blood culture & 11 & 14 \\
Ulcer swab & 7 & - \\
Tracheal aspiration & 7 & 3 \\
Sputum & 1 & 1 \\
Tissue biopsy & 2 & 1 \\
Abscesses / free & 1 & 2 \\
abdominal fluid & & \\
Urine & 1 & 9 \\
\hline
\end{tabular}

\section{Media and culture conditions}

For the experiments, MRSA, VRE, and CRK strains were cultured in Tryptic Soy Broth (TSB) at $37^{\circ} \mathrm{C}$ in aerobic conditions for 24 hours. For isolation of lactobacilli, de Man Rogosa Sharpe (MRS) broth was used, bacteria incubated under anaerobic conditions at $37^{\circ} \mathrm{C}$ for 48 hours.

The overnight cultures of lactobacilli were centrifuged at $4000 \mathrm{rpm}$ for 30 minutes at $4{ }^{\circ} \mathrm{C}$ then the supernatants were filtered by using a 0.2 $\mu \mathrm{m}$ filter (23). In the experiments, diluted $(25 \%$ and $50 \%$ ) and non-diluted cell-free supernatants (CFSs) from each of the lactobacillus strains were used to determine the most effective inhibitory concentration.

The detection of growth alterations of MRSA, CRK, and VRE strains in the presence of cellfree Lactobacilli supernatants

The initial concentrations of bacteria were $10^{7}$ $\mathrm{CFU} / \mathrm{mL}$. Bacteria were cultured into TSB alone (as control) and TSB added different CFSs of lactobacilli $(80 \mu \mathrm{l} \mathrm{TSB}+20 \mu \mathrm{l}$ bacteria and $100 \mu \mathrm{l}$ CFS). We incubated all strains at $37{ }^{\circ} \mathrm{C}$ for 4 hours and the growth was measured according to their absorbance values at $600 \mathrm{~nm}$. The differences in optic density values obtained from control and experimental conditions were compared. All experiments were repeated twice.

\section{Statistical analysis}

Statistical analysis was determined using oneway ANOVA followed by Dunnett's multiple comparisons test and Kruskal-Wallis test. Multiple comparisons were made at a level of $\mathrm{P}<0.05$.

\section{RESULTS}

In the present study, we found that all CFSs at all concentrations inhibited MRSA growth. (Figure1a-1c) and the difference was statistically significant $(p<0.0001)$. All $50 \%$ diluted-CFSs have been found most effective on MRSA strains (Figure-1b).
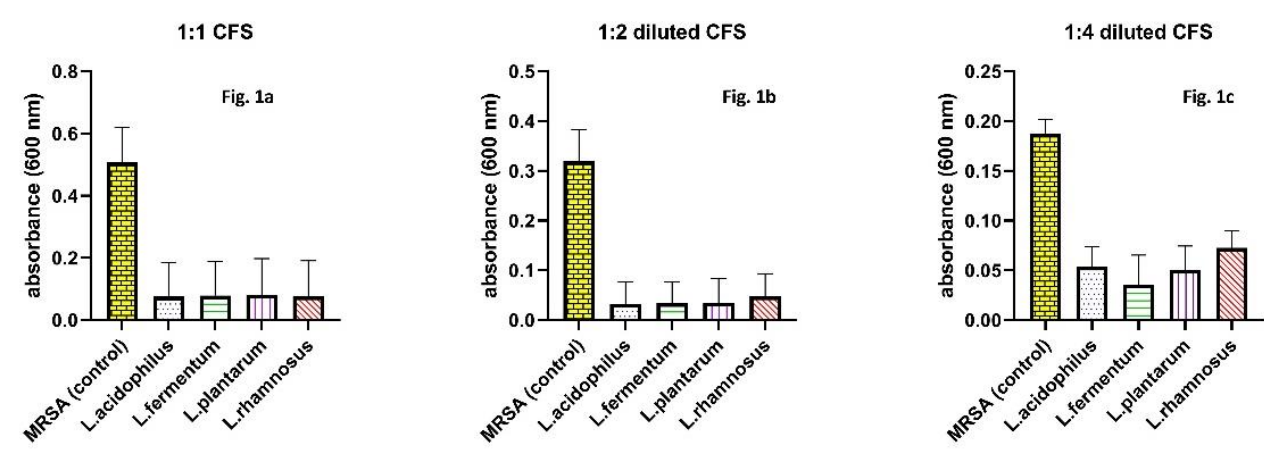

Figure-1. The effects of various lactobacilli CFSs on the growth of MRSA strains. The significance of growth inhibition was determined by comparing growth under control conditions (only MRSA growth, without CFS). The statistical analysis was done using one-way ANOVA followed by Dunnett's multiple comparisons test. The significant differences were at $p<0.0001$ level. 

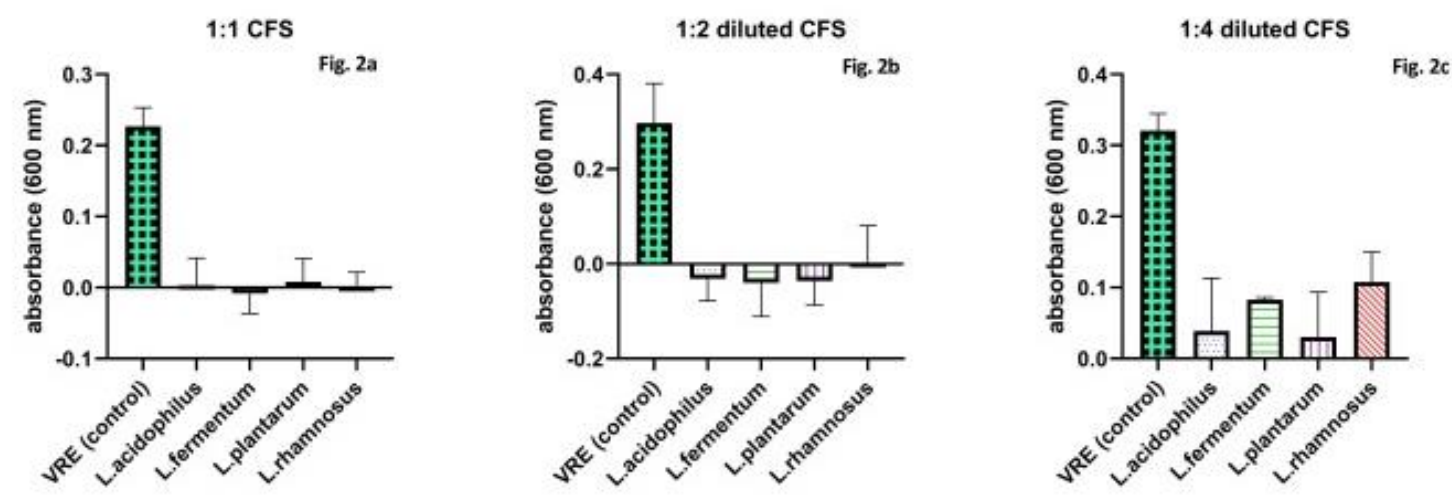

Figure-2. The effects of various lactobacilli CFSs on the growth of VRE strains. The significance of growth inhibition was determined by comparing growth under control conditions (only VRE growth, without CFS). The statistical analysis was done using one-way ANOVA followed by Dunnett's multiple comparisons test. The significant differences were at $p<0.0001$ level.
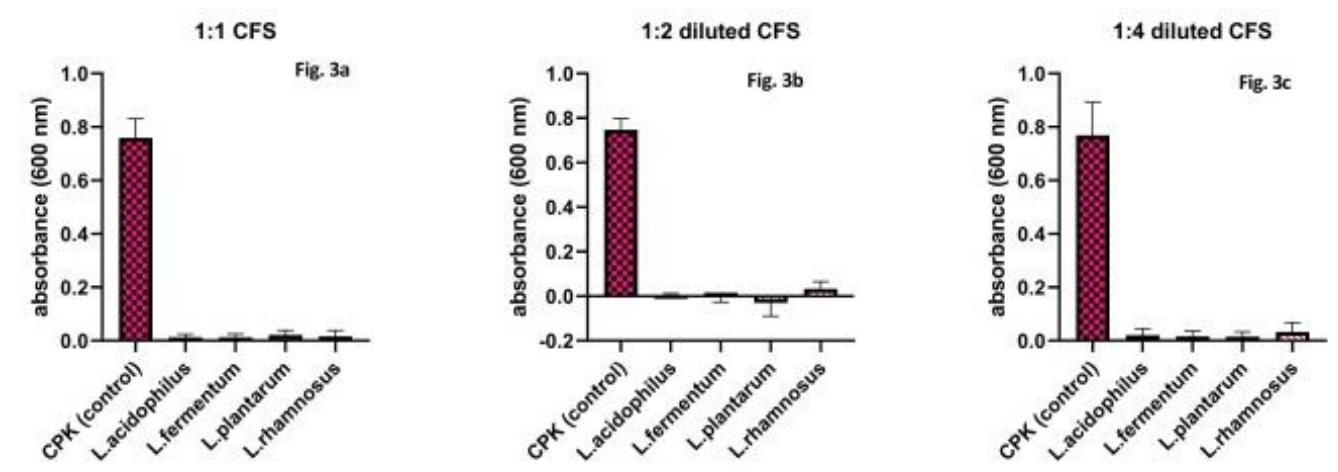

Figure-3. The effects of various different lactobacilli CFSs on the growth of CRK strains. The significance of growth inhibition was determined by comparing of growth under control conditions (only CRK growth, without CFS). The statistical analysis was done using one-way ANOVA followed by Kruskal-Wallis test. Significant difference at $p<0.0001$ level.

All tested CFSs and their concentrations were also found to decrease the growth of VRE strains, and these results were statistically significant $(p<0.0001)$ when compared to control (Figure-2a-2c). L. fermentum's non-diluted-CFS has been found as the most effective antibacterial compound on VRE strains (Figure2a). All CFSs, except CFS of L. rhamnosus, at $50 \%$ concentration were found to the most inhibitory effect on VRE growth than other concentrations (Figure-2b).

All tested CFSs at all concentrations were found to reduce the growth of CRK strains (Figure-3a$3 c$ ). The growth reduction was found to be statistically significant $(p<0.0001)$ for all CFSs. $50 \%$ diluted-CFSs of $L$. fermentum and $L$. plantarum have been found as the most effective antibacterial compounds on CRK strains (Figure3b).

\section{DISCUSSION}

It is well known that antibiotic resistance is a major and growing problem in the treatment of infectious diseases, thus alternative strategies are investigated. In our study, we evaluated the in-vitro inhibitory effects of various CFSs obtained from lactobacillus species on clinically multidrug-resistant MRSA, VRE, and CRK strains which are known as concerning resistance patterns all around the world.

It has been reported that lactobacilli can increase the phagocytosis of macrophages and prevent the colonization of pathogens by competing with other microorganisms and/or by providing hydrogen peroxide, lactic and organic acids, bacteriocins and bio-surfactants to modulate environmental conditions (24-28). In accordance with these effects, it is well known that lactobacilli are the most investigated probiotics; their 
preventive and supportive effects against pathogens have been detected in experimental studies and clinical trials (9-15, 29-32). Previous studies have proven that lactobacilli and their CFSs have effects on growth, adhesion, invasion, biofilm formation, oxidative damage, bacterial cell membrane permeability and gene expression of microorganisms (24, 33-35). Moreover, some in vivo studies also supported these inhibitory effects of lactobacilli $(15,32)$.

In recent years, attention is directed to the inhibitory effects of probiotics on multi-drug resistant, problematical bacteria. Onbas et al. (2019) reported that CFS of L. plantarum strain inhibited the growth of different MRSA strains isolated from skin infections and they suggested that, a product of $L$. plantarum represents a proper strategy for bio-control against wound infections (32). In Malaysia, CFSs of six different L. acidophilus strains isolated from honey samples were shown to inhibit the growth of multi-drug resistant bacteria ( $S$. aureus, $S$. epidermidis and $B$. subtilis strains) in a $\mathrm{pH}$ dependent manner (9). Therefore, acidic $\mathrm{pH}$ of CFSs was found to be important for their antibacterial effects. Similarly, Bhola and Bhadekar (2019) showed that the mixed cell lysate of different lactobacilli strains inhibited the growth of multi-drug resistant Staphylococcus isolates at a rate of $85 \%$ (10). We found that CFSs of all lactobacilli strains we tested have inhibitory effect on growth of MRSA strains. Particularly, we found that the most effective inhibitory concentration was $50 \%$ for all CFSs. Thus, it seems that lactobacilli products have an important potential for the prevention of $S$. aureus growth.

There are also many studies reporting effects of CFSs obtained from various lactobacilli on problematical resistant Gram-positive bacteria other than MRSA (36-38). Naderi et al. (2014) indicated that $L$. acidophilus, $L$. casei and $L$. rhamnosus have no antagonistic effect against multi-drug resistant Enterococcus species which were isolated from urinary tract infections (14). In contrast to these results, Sun et al. (2009) concluded that $L$. rhamnosus decreased the growth of E. faecalis (39). Similarly, Thanh et al. (2010) have shown that the metabolites of different $L$. plantarum strains' combinations inhibited the growth of S.Typhimurium, E.coli, L. monocytogenes and VRE (40). This result is consistent with those obtained by Mahdi et al.
(2012), CFSs of $L$. fermentum obtained from vaginal swabs shown to have significant antibacterial activity on $E$. faecalis and $E$. faecium strains (41). In line with these studies, our findings indicated that all lactobacilli CFSs at all concentrations had an antibacterial effect on VRE strains. Moreover, when we used the non-diluted CFSs, we found that $L$. fermentum had the most antagonist effect than others. It is worthy to note that, CFSs of $L$. acidophilus, $L$. fermentum and $L$. plantarum, at $50 \%$ concentrations were found to be most effective.

Similar findings were reported in studies on growth of gram-negative bacteria $(11,12,14,22$, 25, 34, 35, 42). Chen et al. (2019) have shown that $L$. paracasei, L. plantarum and L. rhamnosus strains inhibit the growth of carbapenem-resistant Escherichia coli and Klebsiella pneumoniae strains (11). Fedorova et al. (2017) have suggested that $L$. rhamnosus, $L$. reuteri and Lactobacillus helveticus had significant antagonistic activity against multiple antibioticresistant Klebsiella pneumoniae strains (43). The study conducted by El Mokhtar et al. (2020) has shown that $L$. acidophilus's CFS reduced the growth of ESBL producing $K$. pneumoniae and $P$. aeruginosa strains in a time-dependent manner. They also concluded that usage of CFS may become an effective strategy to overcome infections caused by these resistant bacteria (12). Raras et al. (2019) showed that the cell viability rate of $K$. pneumoniae strain isolated from a patient with severe pneumonia decreased to $29.77 \%$ in the presence of CFS of lactobacilli isolated from kefir (44). On the contrary to these results, Naderi et al. (2013) reported that $L$. acidophilus, $L$. casei, and $L$. rhamnosus have no antagonistic effect against multi-drug resistant $K$. pneumoniae and Enterobacter species isolated from urinary tract infections. They also found that only the growth of $E$. coli strains was inhibited in the presence of CFSs which are defined as resistant to 8 or 9 different antibiotics. L. casei was reported as the most effective probiotic (14). Inconsistent with Naderi, Saud et al. (2020) detected that CFSs of lactobacilli strains isolated from milk, were shown to have no inhibitory effects on multi-drug resistant Klebsiella and Shigella species; however it was shown that $S$. aureus, E. coli, Salmonella Paratyphi, Salmonella Typhi, Pseudomonas, Proteus, Acinetobacter strains were inhibited in the presence of CFSs (45). Gumus et al. (2020) have shown that the growth and biofilm formation of clinically isolated 
Uropathogenic E.coli (UPECs) were inhibited in the presence of $L$. rhamnosus, $L$. fermentum, $L$. acidophilus and L. plantarum CFSs (42). In the present study, we found that all CFSs and all concentrations have inhibitory effect on CRK. Furthermore, L. fermentum and L. plantarum's CFSs at $50 \%$ dilutions were found to be the most effective against CRK.

\section{CONCLUSION}

Consistent with other studies, our results have shown that the inhibitory effects of CFSs of lactobacilli were found to vary depending on lactobacilli species, pathogens and concentration $(11,42)$.
With regard to our results, it is obvious that CFSs of L.acidophilus, L.fermentum, L.plantarum and L.rhamnosus inhibited the growth of MRSA, VRE, and CRK strains most effectively at 50\% concentration. In accordance with previous studies, we expect, these findings will contribute for the development of alternative and preventive strategies for infectious diseases.

\section{Conflict of interest}

There is no conflict of interest to disclose.

\section{Acknowledgment}

Ethical approval has been obtained from Istanbul Yeni Yüzyıl University The Research Ethics Committee. Meeting Date: 11.01.2021 No: 01 562.

\section{References}

1. Wright GD \& Sutherland AD. New strategies for combating multidrug-resistant bacteria. Trends Mol Med 2007; 13 (6): 260-7.

2. Van Duin $D \&$ Paterson DL. Multidrug-resistant bacteria in the community: trends and lessons learned. Infect Dis Clin 2016; 30 (2): 377-90.

3. Falagas ME \& Bliziotis IA. Pandrug-resistant Gram-negative bacteria: the dawn of the post-antibiotic era? Inter J Antimicrobial Agent 2007;29(6): 630-6.

4. Ah YM, Kim AJ \& Lee JY. Colistin resistance in Klebsiella pneumoniae. Inter J Antimicrobial Agent 2014; 44 (1): 8-15.

5. Cattoir V \& Leclercq R. Twenty-five years of shared life with vancomycin-resistant enterococci: is it time to divorce? J Antimicro Chemother 2013; 68 (4): 731-42.

6. Voss A, Milatovic D, Wallrauch-Schwarz C, Rosdahl VT \& Braveny I. Methicillin-resistant Staphylococcus aureus in Europe. Euro J Clin Microbiol Infect Dis 1994; 13 (1): 50-5.

7. Brunel AS \& Guery B. Multidrug resistant (or antimicrobial-resistant) pathogens-alternatives to new antibiotics? Swiss Med Weekly 2017; 147.

8. Oelschlaeger TA. Mechanisms of probiotic actions_a review. Int J Med Microbiol 2010; 300: 57-62.

9. Aween MM, Hassan Z, Muhialdin BJ, Eljamel YA, Al-Mabrok ASW \& Lani MN. Antibacterial activity of lactobacillus acidophilus strains isolated from honey marketed in malaysia against selected multiple antibiotic resistant (mar) gram-positive bacteria. J Food Sci 2012; 77 (7): M364-M371.

10. Bhola $J \&$ Bhadekar R. Invitro synergistic activity of lactic acid bacteria against multi-drug resistant staphylococci. BMC Compl Alter Med 2019; 19(1): 70.

11. Chen CC, Lai CC, Huang HL, Huang WY, Toh HS, Weng TC, ... \& Tang HJ. Antimicrobial activity of Lactobacillus species against carbapenem-resistant Enterobacteriaceae. Front Microbiol 2019;10: 789.

12. El-Mokhtar MA, Hassanein KM, Ahmed AS, Gad GF, Amin MM \& Hassanein OF. Antagonistic Activities of Cell-Free Supernatants of Lactobacilli Against Extended-Spectrum $\beta$-Lactamase Producing Klebsiella pneumoniae and Pseudomonas aeruginosa. Infect Drug Resis 2020; 13: 543.

13. Manzoor A, UI-Haq I, Baig S, Qazi JI \& Seratlic S. Efficacy of locally isolated lactic acid bacteria against antibiotic-resistant uropathogens. Jundishapur J Microbiol 2016; 9:(1).

14. Naderi A, Kasra-Kermanshahi R, Gharavi S, Fooladi AAI, Alitappeh MA \& Saffarian P. Study of antagonistic effects of Lactobacillus strains as probiotics on multi drug resistant (MDR) bacteria isolated from urinary tract infections (UTIs). Iranian J Basic Med Sci 2014; 17(3): 201.

15. Li X, Song L, Zhu S, Xiao Y, Huang Y, Hua Y, ... \& Ren Z. Two strains of lactobacilli effectively decrease the colonization of VRE in a mouse model. Front Cell Infect Microbiol 2019; 9:6.

16. FAO/WHO (2001) Joint FAO/WHO Expert consultation on evaluation of health and nutritional properties of probiotics in food including powder milk with live lactic acid bacteria. http://www.fao.org/publications/card/en/c/7c102d95-2fd5-5b22-8faf-f0b2e68dfbb6/ Accessed 21 Jan 2021 
17. Servin AL. Antagonistic activities of lactobacilli and bifidobacteria against microbial pathogens. FEMS Microbiol Rev 2004; 28(4): 405-40.

18. Lau LYJ \& Chye FY. Antagonistic effects of Lactobacillus plantarum 0612 on the adhesion of selected foodborne enteropathogens in various colonic environments. Food Cont 2018; 91: 237-47.

19. Voravuthikunchai SP, Bilasoi S \& Supamala O. Antagonistic activity against pathogenic bacteria by human vaginal lactobacilli. Anaerobe 2006; 12 (5-6): 221-6.

20. Prabhurajeshwar C \& Chandrakanth RK. Probiotic potential of Lactobacilli with antagonistic activity against pathogenic strains: An in vitro validation for the production of inhibitory substances. Biomed Journal 2017; 40 (5): $270-83$.

21. Karska-Wysocki B, Bazo M, Smoragiewicz W. Antibacterial activity of Lactobacillus acidophilus and Lactobacillus casei against methicillin-resistant Staphylococcus aureus (MRSA). Microbiol Res 2010; 165:674-86.

22. Nigam A, Kumar A, Madhusuda HV, Bhola N. In-vitro Screening of antibacterial activity of lactic acid bacteria against common enteric pathogens. J Biomed Sci 2012; 1:4.

23. Saha S, Tomaro-Duchesneau C, Malhotra M, Tabrizian M, Prakash S. Suppression of Streptococcus mutans and Candida albicans by probiotics: an in vitro study. Dentistry 2012; 2 (6):141-8.

24. Merghni A, Dallel I, Noumi E, Kadmi Y, Hentati H, Tobji S, Amor AB, Mastouri M. Antioxidant and antiproliferative potential of biosurfactants isolated from Lactobacillus casei and their anti-biofilm effect in oral Staphylococcus aureus strains. Microb Pathog 2017; 104:84-9.

25. Poppi LB, Rivaldi JD, Coutinho TS, Astolfi-Ferreira CS, Ferreira AJP, Mancilha IM. Effect of Lactobacillus sp. Isolates supernatant on Escherichia coli $\mathrm{O} 157: \mathrm{H} 7$ enhances the role of organic acids production as a factor for pathogen control. Pesq Vet Bras 2015; 35: 353-9.

26. Kim JU, Kim Y, Han KS, Oh S, Whang KY, Kim JN, Kim SH. Function of cell-bound and released exopolysaccharides produced by Lactobacillus rhamnosus ATCC 9595. J Microbiol Biotechnol 2006; 16: 939-45.

27. Stecher B, Hardt WD. Mechanisms controlling pathogen colonization of the gut. Curr Opin Microbiol 2011; 14: 82-91.

28. Alvarez-Olmos MI, Oberhelman RA. Probiotic agents and infectious diseases: a modern perspective on a traditional therapy. Clin Infect Dis 2001; 32 (11):1567-76.

29. Reid G \& Burton J. Use of Lactobacillus to prevent infection by pathogenic bacteria. Microb Infect 2002; 4 (3): 319-24.

30. Tsai CC, Hsih HY, Chiu HH, Lai YY, Liu JH, Yu B \& Tsen HY. Antagonistic activity against Salmonella infection in vitro and in vivo for two Lactobacillus strains from swine and poultry. Inter J Food Microbiol 2005; 102 (2): 185-94.

31. Doron S, Snydman DR \& Gorbach SL. Lactobacillus GG: bacteriology and clinical applications. Gastroenterol Clin 2005; 34 (3): 483-98.

32. Yüksek FK, Gümüş D, Gündoğan Gi \& Küçüker MA. Cell-Free Lactobacillus sp Supernatants Modulate Staphylococcus aureus Growth, Adhesion and Invasion to Human Osteoblast (HOB) Cells. Curr Microbiol 2020; 1-8. https://doi.org/10.1007/s00284-020-02247-1

33. Mundi A, Delcenserie V, Amiri-Jami M, Moorhead S \& Griffiths MW. Cell-free preparations of Lactobacillus acidophilus strain La-5 and Bifidobacterium longum strain NCC2705 affect virulence gene expression in Campylobacter jejuni. J Food Protec 2013; 76 (10):1740-6.

34. de Klerk N, Maudsdotter L, Gebreegziabher H, Saroj SD, Eriksson B, Eriksson OS, ... \& Jonsson AB. Lactobacilli reduce Helicobacter pylori attachment to host gastric epithelial cells by inhibiting adhesion gene expression. Infect Immun 2016; 84 (5): 1526-35.

35. Onbas T, Osmanagaoglu O \& Kiran F. Potential properties of lactobacillus plantarum F-10 as a bio-control strategy for wound infections. Probio Antimicr Prote 2019; 11 (4), 1110-23.

36. Zhang Z, Tao X, Shah NP \& Wei H. Antagonistics against pathogenic Bacillus cereus in milk fermentation by Lactobacillus plantarum ZDY2013 and its anti-adhesion effect on Caco-2 cells against pathogens. J Dairy Sci 2016; 99 (4): 2666-74.

37. Aguilar C, Vanegas C \& Klotz B. Antagonistic effect of Lactobacillus strains against Escherichia coli and Listeria monocytogenes in milk. J Dairy Res 2011; 78 (2): 136. 
38. Tsai CC, Lai TM, Lin PP \& Hsieh YM. Evaluation of lactic acid bacteria isolated from fermented plant products for antagonistic activity against urinary tract pathogen Staphylococcus saprophyticus. Probio Antimicr Prot 2018; 10 (2): 210-7.

39. Sun J, Hu XL, Le GW \& Shi YH. Lactobacilli prevent hydroxy radical production and inhibit Escherichia coli and Enterococcus growth in system mimicking colon fermentation. Letters in Applied Microbiol 2010; 50 (3): 264-9.

40. Thanh NT, Chwen LT, Foo HL, Hair-Bejo M \& Kasim AB. Inhibitory activity of metabolites produced by strains of Lactobacillus plantarum isolated from Malaysian fermented food. Int J Probio \& Prebio 2010; 5 (1): 37.

41. Mahdi LH \& Husain SN. Antagonstic Effect of Lactobacillus Fermentum Supernatant Against Enterococcus faecium and Enterococcus faecalis In Vitro. J Facult Med Baghdad 2012; 54(2):154-7.

42. Gümüş D, Yüksek FK, Bilgin M, Camadan FD \& Küçüker MA. In Vitro Effects of Various Probiotic Products on Growth and Biofilm Formation of Clinical UPEC Strains. Acta Biol Maris 2020; 3(1): 5-14.

43. Fedorova TV, Vasina DV, Begunova AV, Rozhkova IV, Raskoshnaya TA \& Gabrielyan NI. Antagonistic Activity of Lactic Acid Bacteria Lactobacillus spp. against Clinical Isolates of Klebsiella pneumoniae. App Biochem Microbiol 2018; 54 (3): 277-87.

44. Raras TYM, Firdausy AF, Kinanti IR \& Noorhamdani N. Anti-Biofilm Activity of Lactic Acid Bacteria Isolated from Kefir Against Multidrug-Resistant Klebsiella pneumoniae. J Pure Appl Microbiol 2019; 13 (2): 983-92.

45. Saud B, Pandey P, Paudel G, Dhungana G \& Shrestha V. In-vitro Antibacterial Activity of Probiotic against Human Multidrug Resistant Pathogens. Arch Vet Sci Med 2020; 3, 31-9. 